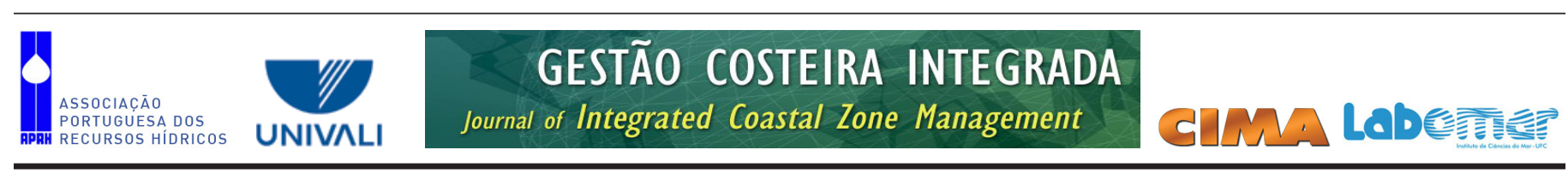

http://www.aprh.pt/rgci/pdf/rgci-402_Echevarria.pdf | DOI:10.5894/rgci402

\title{
Capacity building for local coastal managers: a participatory approach for Inte- grated Coastal and Marine Zones Management in Uruguay *
}

\author{
Capacitação de gestores locais para a zona costeira: metodologias participativas nas \\ áreas marinhas e gestão costeira integrada no Uruguai **
}

\author{
Luciana Echevarría ${ }^{\circledR, 1}$, Alberto Gómez ${ }^{1}$, Clara Piriz ${ }^{1}$, Cristina Quintas ${ }^{2}$, Rafael Tejera ${ }^{1}$, Daniel Conde ${ }^{3}$
}

\section{SUMMARY}

In this paper we present a capacity building experience for local coastal managers in Uruguay which was designed to promote interactions between relevant institutions and stakeholders. The objective was to increase local stakeholders' knowledge of coastal zone problems and of the implications of adaptive, integrated coastal zone management (ICZM) for informed decision making. The course, which was offered to stakeholders at different levels of the governance network, was designed to increase the capacity of participants to understand the reality of Uruguay's coastal zone, meet development challenges, evaluate the need for action to prevent or remedy these challenges, as well as to achieve changes in attitude which are necessary for sustainable communities. Through participating in the course, stakeholders gained the capacity to promote interactions between state interests, government and their own communities since they live in connection with the occupations and dynamism of the zone. ICZM training is the basis for natural resource protection and for improving the quality of life of coastal dwellers. Not only did technicians and local leaders receive training, a regional network of local knowledge and experience in comprehensive ICZM was also created, which has the potential to capitalize on the natural resources found in each area. In addition, the course generated continued commitment to coastal areas management and networking, and promoted new synergies. The link between local managers and academia which was created during this shared educational experience is of fundamental importance for advancing ICZM in Uruguay.

Keywords: Coastal Zone, ICZM, Governance, Education, Uruguay

@-Corresponding author

1 - Centro de Manejo Costero Integrado del Cono Sur. Espacio Interdisciplinario; Universidad de la Republica. Montevideo, Uruguay. e-mail: Echevarría luciana. echevarria@gmail.com,Gómezalgomezba@gmail.com,Piriz mcpiriz@gmail.com,Tejera rafaelOtejera@gmail.com, Conde,vladddcc@gmail.com.

2 - Programa ECOPLATA. Montevideo, Uruguay.e-mail: cristinaquintas@ecoplata.org.

3 - Centro de Manejo Costero Integrado del Cono Sur; Centro Universitario Regional Este; Espacio Interdisciplinario; Universidad de la Republica. Montevideo,

Uruguay.vladddcc@gmail.com.

* Submission: 21 March 2012; Evaluation: 26 April 2013; Reception of revised manuscript: 12 July 2013; Accepted: 31 July 2013; Available on-line: 13 August 2013

** Portuguese Title, Abstract and captions by Ulisses M Azeiteiro on behalf of the Journal Editorial Board 


\section{RESUMO}

Este trabalho descreve uma experiência de capacitação para gestores locais, na zona costeira do Uruguai, que visou promover a interacção entre as instituiçöes e os stakeholders intervenientes. O objectivo do trabalho realizado foi o de alargar o conhecimento dos stakeholders quanto aos problemas na zona costeira e as implicaçōes de uma gestão integrada da zona costeira (GIZC) no processo de decisão. A formação dos stakeholders foi efectuada para os diferentes niveis de governança e foi concebida para alargar a capacidade dos intervenientes na compreensäo da realidade e dos problemas na zona costeira do Uruguai, aç̧óes de prevenção e remediação, mudanças de atitude e sustentabilidade destas áreas e das suas comunidades. Através da sua participação na formação os stakeholders adquiriram capacidades de promoção da interacção entre os interesses públicos e governamentais e as suas comunidades locais. A formação em GIZC é a base para uma melhor proteç̧ão dos recursos e melhoria da qualidade de vida das populaçôes das zonas costeiras. Para além da formação dos técnicos e líderes locais foi criada uma rede integrada de conhecimento e experiencias locais em GIZC que terá o potencial de usar de forma sustentável os recursos naturais de cada área. Além disso o curso gerou um compromisso para o futuro na gestâo destas áreas, criação de redes e promoção de sinergias. A ligaçâa promovida por este projecto educacional de troca de experiências e conhecimentos entre os gestores locais e a academia terá uma importância fundamental na promoção da GIZC no Uruguai.

Palavras-chave: Zona Costeira, GIZC, Governança, Educação, Uruguai.

\section{INTEGRATED COASTAL ZONE MANAGEMENT AND CAPACITY BUILDING IN URUGUAY}

Coastal zones play a vital role in the social-economic evolution of mankind. Due to the abundant resources which it provides, a variety of activities and uses are concentrated in the coastal zone (Cicin-Sain \& Knecht, 1998). Currently, the social demands associated with the various uses and activities of the coastal zone are increasing. In this limited and highly desired zone, social tensions and conflicts may arise where uses and activities converge. Complex supply and demand interactions with respect to territory, natural resources, infrastructure and services exist, increasing anthropogenic pressure on the environment (Ehler et al., 2007).

The Millennium Assessment recognizes that the increasing world population is at the heart of this problem. Permanent population growth, technological progress and changes in consumer demands have led to a substantial modification in food availability, energy share and fluidity of global trade. Therefore, an increasing proportion of goods and services come from coastal and marine resources, and several examples exist where these resources are exploited to their full exhaustion (Beaudoin \& Pendleton, 2012).

For Latin America, coastal marine areas are vital to almost all spheres of social interest leading to deterioration and depletion of natural capital (Barragán Muñoz, 2012). Almost all Latin American countries share the loss or degradation of coastal ecosystems and the services they provide for human welfare. Coastal environments provide ecological goods and services and, since they are generally public spaces, are controlled by the state (Young, 2007).

Uruguay has a coastal zone of approximately $714 \mathrm{~km}$ which is characterized by various types of morphology associated with different ecosystems. The dominant formations along the coast are arches of sandy beaches separated by rocky headlands. In addition to sand dunes, the oceanic coast is characterized by a series of coastal lagoons and marshes (GEO, 2008; Menafra et al., 2009). In recent years, the Uruguayan coast has been transforming at an accelerated rate. A variety of activities such as artisanal and industrial fishing, agriculture, tourism, transportation and maritime trade have led to an expansion of cities and increased settlement in the coastal zone with an intensification of urbanization and of the transportation networks. This has resulted in a significant concentration of the population, accompanied by increased economic activity and infrastructure which largely depends on the coast and must be located in its proximity (Menafra et al., 2009).

One reason for this trend is that the majority of society does not understand the immense value of a sustainable coastal environment, or the cost of its degradation. Coastal managers work in a constantly changing environment with fragmented management efforts which originated from a sectorial (port, fishing, infrastructure, tourism, etc.) or jurisdictional (state, provincial or departmental, municipal) management approach. Currently, coastal management is basically regulatory and based on strong interests and pressures from various sectors.

Integrated Coastal Zone Management (ICZM) assumes interdependence of coastal human communities and associated resources, calls for user conflict resolution and the reduction of cumulative impacts, and considers local participation as a critical management component (Christie et al., 2005). ICZM is regarded internationally as the most advanced approach to vertically and horizontally integrate technical, political and coastal communities, taking into account local adaptation of international experiences. In order to actively participate in ICZM, the problems caused by interactions between people and their physical and biological environment must be considered and understood both socially and culturally. This is necessary in order for people to feel like an integral part of the coastal environment and to work responsibly when confronted with inappropriate uses (Sorensen \& West, 1992).

Adaptive management is a tool that can be used not only to better run a system, but also to learn about the system itself. It uses an integrated approach to cope with uncertainty and complexity in natural systems (Holling, 1978; Walters, 1986), assuming that managed resources will continue to be modified due to human intervention, so surprises and new uncertainties will continuously emerge (Gunderson, 1999).

As part of the holistic approach of ICZM, capacity building plays as a central role in developing the abilities 
of planners, managers and decision makers, to accomplish sustainable management based on new values and behaviors (Novo, 2009). May \& Williams (1986) include the ability to reach set goals, which can be reflected in political, managerial, and technical competences among capacities to be developed. The US Marine Fisheries Service indicates that capacity building also requires strengthening human resources and capabilities for coastal management, science, training and education (May \& Williams, 1986). Crawford (1993) indicates that building institutional capacity for ICZM is a relevant component for the implementation of ICZM plans. Nevertheless, Norris-Raynbird (2003) suggests that visions focused on capacity building as simply the quantitative increase of existing human resources is far from the required dynamic process of building capabilities based on a mutual learning practices.

Capacity building must promote a better understanding of the relevance of biodiversity for the sustainable and equitable use of biodiversity resources (UNEP/UNESCO, 2012) and develop actions to prevent the deterioration of ecosystems in order to ensure their use (Ehler et al., 2007; Pomeroy \& Douvere, 2008). This new vision requires foreseeing human society not as the dominator of its environment but as part of it (Novo, 2009). It also considers the environment globally (e.g. natural and built, technological and social), drawing on specific contents of diverse disciplines in developing a holistic and balanced approach Sinha et al. (1985).

Man came into conflict with coastal systems when attempting to rule nature without fully understanding the basic processes that drive coastal dynamics (Dias et al., 2009). Currently, according to Batzan et al. (2012), main coastal challenges include harmonizing interests of coastal users with improvement of economic instruments, integrating research and education into decision making processes and protecting natural and cultural resources at all levels in order to respect the values of local communities. These challenges require transparent and easily accessible information in order to better guide the decision-making processes. The ICZM principles of identifying the needs of stakeholders and conserving natural resources as common dialectic objectives require participation and capacity building for key actors as an emerging challenge to integrate ideas and actions collectively (Pomeroy \& Douvere, 2008).

In 1970 the IUCN defined environmental education as "the process of recognizing values and clarifying concepts in order to develop skills and attitudes necessary to understand and appreciate the inter-relatedness among humans, their culture and biophysical surroundings" (Hesselink \& Čeřovsky, 2008). Education is an opportunity for building citizenship and empowering political institutions, which requires developing new skills, e.g. to express demands and opinions in the media, to participate in network systems, and to adapt to situations of increasing flexibility. Environmental education needs to be problematized by debating the relationships between society and nature (da Silva \& Rainha, 2013). This challenge requires a broad participation of stakeholders, particularly of local agents assuring innovative solutions towards environmental sustainability (Martínez et al., 2007). These key players are then able to promote articulation mechanisms among stakeholders.
It is noteworthy that the goal of ICZM is to create the basis for establishing policies, plans and local programs in an integrated and participatory approach (Barragán Muñoz, 2012), to advance towards conservation of coastal ecosystems on a long term basis. Developing ICZM processes requires a sustained public policy negotiation which will guide collective action since neither institutions nor people can be excluded from the process. The various levels of government and civil society as a whole need to share with each other their views concerning the future of the coastal zone and its management in order to better organize their actions.

In an ICZM context, the contributions from academic studies are critical for making management decisions based on the best scientific information available. At the university level, Uruguay is a leader in Integrated Coastal Management in the Southern Cone community. This ICZM community includes Mexico, Chile, Brazil and Argentina. In 2009 the "Interdisciplinary Centre for Integrated Coastal Management in the Southern Cone (C-MCISur)" was created at the University of the Republic (UdelaR) with the overall objective of contributing, from the University, to the management of the coastal zone of the Southern Cone through a regional, interdisciplinary approach based on the principles of ICZM, encouraging the creation of knowledge, tools and human resources, in close collaboration with decision makers and civil society (Conde et al., 2012).

One of the specific objectives of the C-MCISur is to improve the capacity of human resources in coastal management in the region. The Centre, through its Education Program, offers a Master's degree in ICZM, whose third cohort is currently underway. It also offers a range of capacity building courses for officials and national experts, as well as for students in the region (www. mcisur.edu.uy).

ECOPLATA Program is a long-term initiative (started in 1992) resulting from cooperation between Uruguay and Canada, aimed at strengthening knowledge of institutions, the scientific community, managers and the general public on aspects related to ICZM in Uruguay. ECOPLATA, in cooperation with C-MCISur, developed a National Program for Education and Training in ICZM, in order to build capacity and develop tools to assist decision-making. One of the objectives for 2014 is the development of effective, long-term programs to contribute to the protection and restoration of coastal morphology, management of dune erosion, and to promote sustainable social and productive use of the coastal zone resources in Uruguay. Training activities and local knowledge development are ideal tools for achieving these objectives.

It must be highlighted that in Uruguay coastal management is carried out by an informal cluster of diverse institutions. ECOPLATA was conceived as a program for creating opportunities to improve the present fragmented management of the coastline. Although it has no formal competences, its main function is to create adequate frameworks for inter-institutional actions concerning coastal issues. This coordination is presently being addressed by a new legislation on coastal management under discussion at the national Parliament. A Management Committee was created by the Territorial Planning act (art. 76 Law 18,308), which is responsible for establishing a national coastal management 
policy. The new act also creates a Coastal Area Observatory, under the jurisdiction of the Ministry of Housing, Spatial Planning and the Environment, in order to track the various processes and territorial planning in coastal areas as well as management plans related to the coast.

\section{VIRTUAL INTEGRATED COASTAL AND MARINE ZONES MANAGEMENT COURSE FOR LOCAL LEVEL DECISION-MAKERS}

Based on the capacity building needs mentioned above, in 2012 the first virtual course on Integrated Coastal and Marine Zones Management was offered in the context of the National Program for Education and Training. This initiative targeted coastal zone decision-makers from fifteen municipalities and technical staff from five provincial governments (officially named Departments) who work on environmental management.

It is important to consider that this course coincides with a new reality in Uruguay, given the adoption in 2009 of a new Law, according to which municipalities, governed by fivemember bodies, were created as a third level of government and administration. The president of this authority, the mayor, and other members known as "councilors", are chosen by public election. Beyond the statutory definition, the responsibilities of the municipalities are still undergoing a process of institutionalization which is being carried out in close contact with local communities.

The law establishes that municipalities will facilitate the active participation of society in local government issues for which they may create the settings and mechanisms deemed necessary. Among other tasks, municipalities can develop projects and resolutions to be presented to the "governor" of the corresponding province, develop regional programs and take preventive measures in environmental protection. In addition, municipalities carry the responsibility for tasks related to roads, public works maintenance, waste disposal, trade and industry promotion, as well as the implementation of social and cultural programs.

Coastal municipalities are facing the challenges of environmental management with basically no training in coastal management. ECOPLATA asked the C-MCISUR to assist with in capacity building for local stakeholders at the municipal level. Therefore, a course was designed to increase the capacity of participants from municipalities to understand what is presently happening on the coastal zone and to evaluate the need for action in order to prevent or remedy these challenges.

The promotion of the course was done by ECOPLATA Program, which has permanent contacts with provincial and municipal authorities. Authorities, managers and technicians from all provincial and municipal governments along the coastal zone were invited. Since the course was aimed particularly at institutional actors, there was no public promotion.

The objectives of the course were to build capacity for understanding the implications of integrated and adaptive management towards informed, solid decision making, and raise awareness about the value of the coastal zone and its vulnerability. Due to the fact that participants came from a variety of locations and diverse backgrounds, the methodology used involved a combination of virtual modules and face-to-face workshops. This involved the challenge of implementing the theoretical component by distance education and conducting workshops in various locations.

\section{Participants}

The first edition of the course was attended by fifty participants from nineteen municipalities (out of a total of twenty-eight coastal municipalities) from the six coastal provinces of Uruguay, including top and middle municipality authorities (majors and councilors), but also mid-level authorities, managers, and officials from diverse levels from both municipal and provincial governments (Table 1). Twelve percent of attendants were mayors, $42 \%$ were councilors, and $46 \%$ were officials. As a whole, provincial and municipal governments were equally represented. Provinces closer to the area where the course workshops were held (San José, Montevideo, Canelones and Maldonado) had greater representation (96\%) than Colonia and Rocha (4\%), the two provinces farther away from the Metropolitan area. The province best represented was Maldonado, with 36\% of the total of attendees.

The virtual component was developed using the EVA platform of UdelaR. This course management system allowed us to manage and track educational tasks through forums, chats, a library of materials, academic material, etc. Creating a virtual space for posting information and sharing coastal management experiences in Uruguay is one of the most interesting contributions, nourishing and energizing the training process with information and knowledge.

The face-to-face component consisted of five workshops in two regions: the Western Region which included the provinces of Colonia, San José and Montevideo, and the Eastern Region, including Canelones, Maldonado and Rocha. The workshops focused on bringing about cultural change with regards to the coastal zone and ICZM.

\section{Course contents}

The course was based on an interdisciplinary framework, presenting the different disciplines as interrelated, and not as an accumulative process. The course materials were also created through interdisciplinary team work. The course also recognized the research-action principle as a relevant approach in ICZM, assuming knowledge is not only the response to an intellectual curiosity, but that it has the objective of transforming society, which, in our case is relevant since most of the participants are stakeholders closely linked to local social problems faced by local communities. The opportunity for transformation of local reality through participatory action is thus created (Fals-Borda, 1981; Barquera, 1986; Smith et al., 1993).

The course content provided guidelines for analyzing issues related to coastal areas and fostering a critical and committed attitude towards finding solutions to coastal problems, based on good management. The course was organized into six modules and three workshops (Figure 1): 
Table 1. Number of course attendees according to province and their government role.

Tabela 1. Número de formandos nos cursos de acordo com a sua provincia de origem e cargo governamental.

\begin{tabular}{l|l|c}
\hline $\begin{array}{c}\text { Department } \\
\text { (Province) }\end{array}$ & \multicolumn{1}{c}{ Role } & $\begin{array}{c}\text { Number of } \\
\text { participants }\end{array}$ \\
\hline Colonia & Municipal mayors & 1 \\
\hline \multirow{2}{*}{ San José } & Municipal councilors & 2 \\
\cline { 2 - 3 } & Officials from environmental management divisions & 9 \\
\hline \multirow{2}{*}{ Montevideo } & Officials from environmental management divisions & 10 \\
\hline \multirow{3}{*}{ Canelones } & Municipal mayors & 3 \\
\cline { 2 - 3 } & Municipal councilors & 5 \\
\cline { 2 - 3 } & Coastal management foreman & 1 \\
\cline { 2 - 3 } & Coordinator of coastal municipal mayors & 1 \\
\hline \multirow{2}{*}{ Maldonado } & Municipal mayors & 1 \\
\cline { 2 - 3 } & Municipal councilors & 12 \\
\cline { 2 - 3 } & Provincial councilors & 2 \\
\cline { 2 - 3 } & Lifeguards coordinator (provincial government) & 1 \\
\cline { 2 - 3 } & Coordinator of Environmental Education (provincial government) & 1 \\
\hline \multirow{2}{*}{ Rocha } & Beach foreman (municipal level) & 1 \\
\hline
\end{tabular}

- Module One (Introduction to ICZM) defined the coastal zone in space and time, human society as agents of coastal change and introduced the concept of Integrated Coastal Zone Management.

- In Module Two the basic concepts of Land Planning were discussed, considering the territory as an environmental matrix, the territory as a process and the territory as a project. Different theoretical focuses and basic planning concepts were discussed.

- Module Three was devoted to the legal aspects of ICZM, general management structure of the state, protection of the environment and of coastal areas, and the concept of participation.

- Module Four focused on coastal ecosystems, specifically on ecosystem types, functioning, conservation and use, and on coastal habitats and biota.

- Module Five discussed environmental impacts in the coastal zone and adjacent areas, the types of environmental impacts on the coast and the tools for prevention and mitigation of environmental these impacts.

- Module Six was dedicated to governance and comanagement of the coast and coastal management, the concept of governance, the concepts of participation and co-management, and presentation of national and international case studies.

\section{Course Methodology}

The methodology used to plan and carry out the course reflected the fundamental principles of ICZM. The curriculum of the course addressed the coastal zone as an integrated area and the different topics were incorporated into this framework, based on the principles and phases of ICZM (Fig.1). While thematic modules belonged to different areas of knowledge, the approach recognized the coastal zone as a complex whole. Each topic incorporated principles and knowledge from the other areas as well as practical experiences and exchange, avoiding isolated academic development.

We used a course management system (CMS - Course Management System or LMS - Learning Management System) that allowed us to manage and record all educational tasks through the use of a forum, a library of materials, calendars, academic material, etc. The "exchange forums" were key virtual opportunities to increase the comprehension and diversity of topics. This tool allowed fluid communication between all participants, so that they could exchange views on practical issues raised by the teaching staff as well as other issues that arose in the forum which lead to collaborative learning. In the forum concerns were raised, local experiences were presented and teachers added contributions that facilitated a diversity of inputs for each topic.

The online course was complemented by face-to-face regional thematic workshops, which became a fundamental part of the course. Getting to know the other participants and the teachers was also of great importance for enhancing 


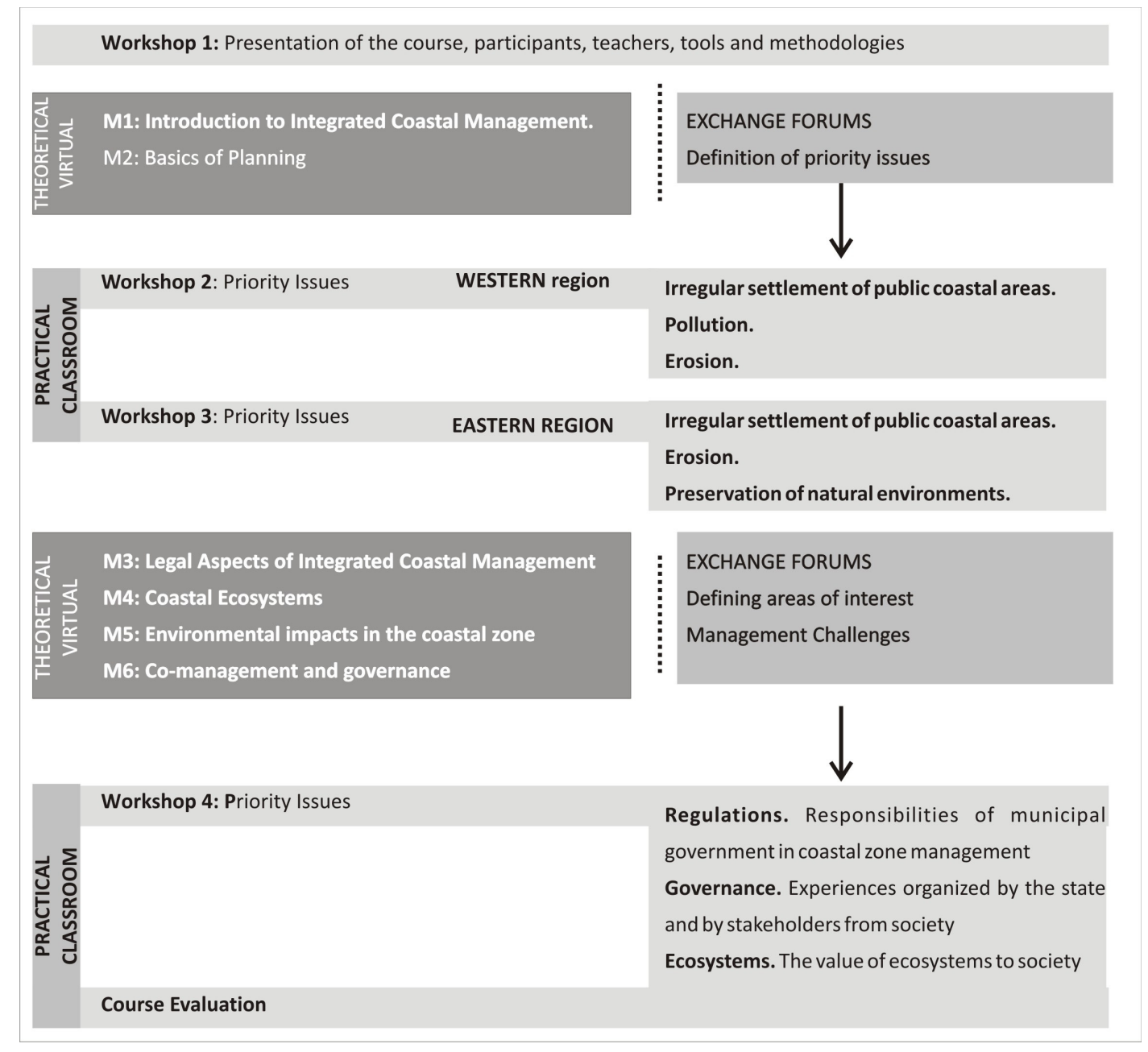

Figure 1. Organization of the curriculum of the Virtual Integrated Coastal and Marine Zones Management Course.

Figura 1. Organização curricular do Curso Virtual de Gestão Integrada da Zona Costeira.

the application of knowledge in local governance networks. During the first workshop the course was introduced and the tools and methodology were presented so that students and teachers would be able to use the EVA platform. During this workshop, the virtual users were created, the level of knowledge of all participants was evened out, and the tools to be used in the course were tested. In the following three workshops the theoretical concepts which had been discussed in the different modules were applied to specific situations. Participants selected the topics during the virtual course and these reflected a diversity of situations from the different locations.

In workshops 2 to 4 , participants deepened their understanding of the main management challenges, observing the characteristics of the conflicts proposed, the stakeholders involved and the possible actions to resolve them. The workshops were divided into three segments:

- Segment 1: Participants, their area or work and interests, content and methodology were introduced.

- Segment 2: Participants worked in groups to select and analyze specific examples from the subject areas and to develop proposals.

- Segment 3: The results from each group were presented and the activity was evaluated.

In these workshops, the cases which had previously been studied were discussed creating a link between the course and management in the real world, and giving the participants an opportunity to interact. The workshops served as a lens, focusing in on key issues and contributing to future dialogue agendas for each of the topics. During workshops 2, 3 and 4 the groups worked with the support of experts from each subject area, who coordinated the group task and encouraged participants to examine the realities in each of their municipalities with respect to each topic.

Main priority issues identified during workshops 2 and 3 were (see Table 2) (1) irregular occupation of coastal areas, (2) pollution, (3) erosion, and (4) preservation of natural environments. For each topic, priority issues and potential actions were identified, and are listed in table 2. It was observed that artisanal fisheries and irregular occupation of 
coastal zones was a relevant topic throughout the coast, while pollution, in particular the management of solid wastes, was a priority topic for Montevideo and San José, due to the large population of this metropolitan area. Another topic of spatial significance was erosion, mostly related to lack of planning and regulations about use of the coastal zone. Finally, the preservation of natural habitats was seen by participants from Canelones, Maldonado and Rocha as a major concern, especially wetland areas: The natural values of these environments were recognized by local people, as were the ecosystem services they offer.

Workshop 4 addressed coastal governance (see Table 3), tackling the linkages between state and civil society, and focusing on establishing the degree of progress al ready reached in diverse sections of the coast and the kind of difficulties and challenges of the present situation. The discussions included concrete experiences, both top-down, i.e. originated from state initiative, and bottom up, i.e. arisen from social actors), in which the main problems and the present level of policy development were defined for each of the coastal provinces (listed in table 3). The cases analyzed showed that bottom-up experiences on the coast of Uruguay are far more advanced and successful than top-down practices, which in in some cases reached the implementation and evaluation phases of the ICZM cycle.

\section{Course assessment highlights}

After the course, participants and teachers were asked to express their opinions in order to improve future courses. Highlights from the assessment include:

- The use of the virtual platform presented several challenges, some of which could be resolved but others could not. However, it was agreed that because of the commitments which participants had to fulfill outside the course, and because participants came from many different locations, this method was a viable solution.

- The combination of virtual modules and face-to-face workshops was fundamental to the participants and for reaching the objective of the course, as local working conditions (often voluntary and field based) would have made long absences from the workplace impossible.

- Participants commented that the workshops were very useful for exchanging ideas and opinions and for studying relevant cases related to the corresponding theoretical modules.

- The teachers' commitment was underscored and their enthusiasm for the subject matter and the learning process made the participants feel supported.

- The suggestion was made that the course should be offered to a greater number of managers, highlighting the importance of strengthening networks and involving a critical mass of informed decision makers at different levels in integrated coastal management.

After the course, an evaluation questionnaire was sent to all participants, requesting their opinion on the degree of interest for the activity, on the virtual modality and the platform used, and on the usefulness of the course contents and the regional workshops. From these results, and also based on their own opinion, the course teachers developed an analysis (SWOT analysis) of the course contents and of the methodology used. Results are shown in Table 4. As can be seen, many strengths and opportunities (mainly concerning the utility of the virtual modality and the derivation of post course actions; see also table 5) arose from the analysis, while relatively few weaknesses and threats were identified (although attention must be paid to the difficulties which some participants experienced with the platform).

\section{Lessons learned}

Several lessons learned emerged from a critical assessment carried out by the two leading institutions, analyzing the process of the virtual course from beginning to end. Capacity building, understood comprehensively incorporates knowledge, but also relationships with others (other places, other stakeholders), implies potential networks and requires understanding in order to act, visualizing the results as exchanges of concrete actions in the coastal area. Capacity building is seen as a process of articulation of social capital at the local level with the potential to capitalize on the natural resources of each area, and to generate a continuing commitment to take action toward coastal zone management and to promote new synergies and networks. This approach to capacity building associated with socialenvironmental systems, requires the integration of available scientific knowledge with governance mechanisms. It also requires strategies that fit the principles and best practices of the culture and the specific needs of each location (Olsen $\&$ Ochoa, 2007).

This course also enriched the dynamics of the teaching team, which took a step towards transdisciplinarity as they analyzed problems and visions together with mayors, councilors and government officials. The experience reached a higher stage of disciplinary integration based on common goals and epistemological and cultural unification, which coordinates scientific knowledge with extra-scientific experience and practical problem solving. The link between local stakeholders and academia plays an important role and has been recognized as one of the pillars for advancing ICZM in Uruguay (Menafra et al., 2009). This course not only involved training technicians and local leaders on coastal issues, but also generated a regional network of local knowledge and ICZM experience.

Providing theoretical material and focusing on leveling out the participants' knowledge, as well as providing easy access to technology for everyday use, were indirect results which should also be considered. A better understanding of institutional resources and identifying contact people to facilitate consultations and coordination of coastal management was also a secondary product, which strengthens the management capabilities of participants and suggests that the new capacities they have gained will be useful in the future. Another valuable aspect is the incorporation of new ways to analyze, read and understand the coastal zone, which promotes new ways of valuing, thinking about and interacting with the environments in which the managers work. 
Table 2. Systematization of priority issues and proposed actions addressed during workshops 2 and 3. Tabela 2. Sistematização dos assuntos prioritários e acçôes propostas no decurso dos workshops 2 e 3.

\begin{tabular}{|c|c|c|}
\hline Topic & Priority issues & Proposed actions \\
\hline \multirow{3}{*}{ 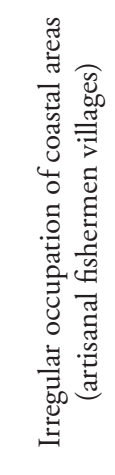 } & $\begin{array}{l}\text { Lack of effective responses to cope with irregular } \\
\text { settlements (e.g. West Montevideo) }\end{array}$ & $\begin{array}{l}\text { - To coordinate between provincial government, municipalities, Coastal } \\
\text { Guard and Home Office to improve monitoring } \\
\text { - To highlight the role of beach foreman for monitoring }\end{array}$ \\
\hline & $\begin{array}{l}\text { Conflicts of between recreation and fishing (e.g. West } \\
\text { Montevideo) }\end{array}$ & $\begin{array}{l}\text { To apply land planning options (e.g. development of local, partial or } \\
\text { special plans) according to law }\end{array}$ \\
\hline & $\begin{array}{l}\text { Need to involve housing policies to manage the } \\
\text { problem: the relocation of fishing settlements located } \\
\text { on the beach, (e.g. i) Wilson colony case: relocation } \\
\text { / retirement; ii) Ciudad de la Costa: stopping the } \\
\text { occupation) }\end{array}$ & $\begin{array}{l}\text { To provide strategic definitions of housing policy to include the } \\
\text { relocation of fishermen in priority areas, combined with development } \\
\text { policies addressing housing issues along with productive policies }\end{array}$ \\
\hline 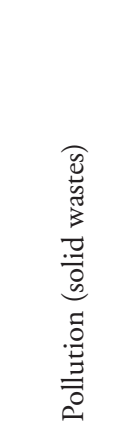 & Pollution of Montevideo Bay & $\begin{array}{l}\text { To develop an integrated management plan for solid wastes, including: } \\
\text { - Information of the impacted areas, stakeholders and interests } \\
\text { - List of lack of information and data necessary for management } \\
\text { - Working in multidisciplinary teams } \\
\text { - Installation of devices impeding plastic wastes reaching beaches } \\
\text { - Develop environmental education activities } \\
\text { - Improve inter-institutional coordination } \\
\text { - Develop economic incentives for enterprises to avoid using plastic } \\
\text { containers } \\
\text { - To develop an alternative project of public space recreational use, to } \\
\text { avoid future settlements }\end{array}$ \\
\hline \multirow{5}{*}{$\underset{\substack{0 \\
\hdashline}}{0}$} & $\begin{array}{l}\text { Works of infrastructures that modify coastal dynamics } \\
\text { (e.g. breakwaters and jetties affecting the sand balance, } \\
\text { generating erosion }\end{array}$ & $\begin{array}{l}\text { To discourage the use of existing or new coastal boulevards or routes and } \\
\text { to develop proposing alternative ways of perpendicular connection or } \\
\text { parallel to the coast but at a larger distance from the coastline }\end{array}$ \\
\hline & $\begin{array}{l}\text { Access by residents and tourists to the beach in places } \\
\text { not permitted, generating sand blowouts }\end{array}$ & $\begin{array}{l}\text { - To study the design and location of accesses to beaches specifically for } \\
\text { each location } \\
\text { - To encourage the use of wooden stairs and/or mobile wooden carpets } \\
\text { on the dunes, so to avoid impact on the primary sand dune system } \\
\text { (e. g. Paraíso Suizo seaside) }\end{array}$ \\
\hline & Sand extraction and vehicle traffic on the dunes & $\begin{array}{l}\text { - To prohibit extractive activities on beaches and dunes } \\
\text { - To carry on regulatory actions associated with uses in the coastal area } \\
\text { (e.g. sand and gravel extraction) and monitoring } \\
\text { - To strengthen the presence of Coastal Guard on conflictive zones } \\
\text { - To highlight the role of beach foreman or "coastal rangers" for } \\
\text { monitoring. }\end{array}$ \\
\hline & Dunes immobilization with exotic plant species & $\begin{array}{l}\text { To replace with plant species favoring dune reconstruction: e.g. } \\
\text { psammophile vegetation }\end{array}$ \\
\hline & $\begin{array}{l}\text { Paving, draining Works and channeling of pluvial waters } \\
\text { towards the beach (e.g. Piriápolis, La Floresta) }\end{array}$ & $\begin{array}{l}\text { To study each site specifically for alternative drainage or storm water } \\
\text { conveyance not affecting the coast }\end{array}$ \\
\hline 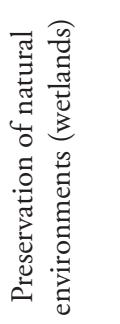 & $\begin{array}{l}\text { Activities incompatible with wetland conservation (e.g. } \\
\text { La Alameda, south of San Carlos city) }\end{array}$ & $\begin{array}{l}\text { - To develop education and communication strategies to raise awareness } \\
\text { of the ecosystem and cultural values of the area, and to develop } \\
\text { patterns for wetland and water resources conservation } \\
\text { - Design and implementation of a "linear park" project as a strategy for } \\
\text { conservation and to give greater visibility to the problem, generating a } \\
\text { public debate on the conservation and use of the territory }\end{array}$ \\
\hline
\end{tabular}


Table 3. Cases surveyed during Workshop 4 which addressed Governance, showing the outcomes of top-down experiences (originated from state initiative) and bottom-up cases (arisen from social actors).

Tabela 3. Estudos de caso do workshop 4 sobre Governança e resultados das experiências top-down (iniciativas governamentais) e dos casos bottom-up (da iniciativa dos actores sociais).

\begin{tabular}{|c|c|c|c|}
\hline Origin & Case & $\begin{array}{l}\text { Present level of policy } \\
\text { development }\end{array}$ & Problems and challenges during the process \\
\hline \multirow{4}{*}{ Top down } & $\begin{array}{l}\text { Organization of neighbors to treat } \\
\text { problems of industrial sand extraction } \\
\text { (San Jose) }\end{array}$ & $\begin{array}{l}\text { Recent inclusion into the } \\
\text { political agenda }\end{array}$ & $\begin{array}{l}\text { Difficulties in establishing stakeholders supporting provincial } \\
\text { government initiatives }\end{array}$ \\
\hline & $\begin{array}{l}\text { Proposal of a protected area in St. Lucia } \\
\text { Wetland (Montevideo - Montevideo - San } \\
\text { Jose) }\end{array}$ & Under design & $\begin{array}{l}\text { Problems of concretion. Very long negotiation process with } \\
\text { institutional difficulties to reach a common view }\end{array}$ \\
\hline & $\begin{array}{l}\text { Relocation of informal artisanal fishermen } \\
\text { (Colonia Wilson - San Jose) }\end{array}$ & Under design & $\begin{array}{l}\text { Problems of concretion. Fishermen who would be displaced } \\
\text { abandoning negotiations with institutions, creating potential } \\
\text { problems of legitimacy of the decision - making process }\end{array}$ \\
\hline & $\begin{array}{l}\text { Citizen network of fire prevention } \\
\text { (Montevideo) }\end{array}$ & Feedback phase & $\begin{array}{l}\text { Successful process for soliciting and implementing the } \\
\text { network. Neighbors trained and linked to the government } \\
\text { with respect to prevention. Neighbors integrate new } \\
\text { commissions for dialogue with institutions. New complex } \\
\text { challenges arise that cannot be addressed only through the } \\
\text { network }\end{array}$ \\
\hline \multirow{3}{*}{ Bottom up } & Abrazo del Solís (Maldonado) & $\begin{array}{l}\text { Recent inclusion into the } \\
\text { political agenda }\end{array}$ & $\begin{array}{l}\text { Set generated coordination between neighbors on both } \\
\text { shores of Solis Grande river. Protection of native riparian } \\
\text { forest as a major objective. Successful call on both provincial } \\
\text { governments to carry out the plan }\end{array}$ \\
\hline & Santa Mónica (Maldonado) & Under implementation & $\begin{array}{l}\text { Successful creation of a network of neighbors to enforce } \\
\text { the ban on driving on sand dunes (signage, and pylons to } \\
\text { prevent the passage of vehicles). Design of a fast response } \\
\text { system to report non-compliance }\end{array}$ \\
\hline & Punta Yeguas Park (Montevideo) & Under evaluation & $\begin{array}{l}\text { Park management is led by a group from civil society that to } \\
\text { prevent the area from becoming privatized. Currently, their } \\
\text { authority is being questioned since they were chosen many } \\
\text { years ago. }\end{array}$ \\
\hline
\end{tabular}

Table 4: SWOT analysis of the virtual course.

Tabela 4. Análise SWOT do curso virtual.

Strengths:

- Virtual platform available

- Easy content management

- Unlimited users

- High degree of flexibility

- Open software

- Low maintenance cost

- Controllable copyrights

- External access easy to control

- Easy content update

- Diversity of methods used (theoretical classes, bibliography, forums, questionnaires)

- Knowledge staggered according to MCI cycle

- Use of questionnaires to check the learning progress

- Knowledge staggered according to ICZM cycle

- Personal meetings to assess difficulties during the course

Opportunities:

- Course development according to convenience of participants

- Workshops favored intensive teamwork

- Workshops are linked to thematic and territorial projects

- Use of existing local knowledge

- Tracking online participation.

- Content motivates participants

- The priority issues identified by participants allowed agendas and networks to be developed beyond the course

\section{Weaknesses:}

- Technical tools available are limited in the platform

- The system requires regular technical updating

- Internet connection is required

\section{Threats:}

- Lack of coordination during forums lead to some redundancies in contents

- Funding for regional workshops and transfer of participants.

- Problems with using the virtual platform

- Course developed for country's conditions, which prevents or creates difficulties for its regionalization 
Strengthening stakeholder capacity through mutual support, even though the participants were from diverse locations and without a communications network, was a novel aspect of capacity building much appreciated by the participants, the effects of which are not yet known. First steps were taken towards enabling interactions, contact, personal knowledge and electronic networks. The participants shared knowledge about the problems in each location, the actions implemented as well as their strengths and weaknesses. This could be the beginning of considerations about how the governance of changes in each area, could be improved at the local scale (Olsen \& Ochoa, 2007).

In order to generate interest and enthusiasm, it was fundamental to focus the exchange process on generating positive actions that potentially improve environmental conditions, thus making the participants more perceptive and aware. This phase contributes to the first step of the ICZM cycle, according to which the definition of current experience serves as a framework for initiating an intervention (Olsen \& Ochoa, 2007).

\section{FINAL REFLECTIONS AND PERSPECTIVES}

During this capacity building process the importance of raising awareness among key social players, so that they feel encouraged to contribute to the transformation of the development model, became clear. To this end, capacity building for coastal environmental management was part of an educational experience promoting thoughtfulness and changes in the participants' attitude both in their personal lives as well as in their commitment to their communities. This was achieved not only through transfer of information, but rather, the participants took ownership of this transformation The path towards sustainability requires a revolution of the way environmental professionals perceive and solve environmental problems. In the context of globalization, environmental professionals have to develop new personal, interpersonal, societal and technical skills to become active throughout their careers and to be of value in the quest for sustainability (Ferreira et al., 2006).

The central challenge for the course's organizers and teachers was achieving a sense of comprehensiveness from which the participants could attain a logical combination of thinking and participative action, thus contributing to a novel interpretation of coastal phenomena and land management. This course on social-environmental systems exceeded the traditional sectorial vision, instead considering coastal environments as systems linked with people (Olsen \& Ochoa, 2007).

It is interesting to note that the course had additional impacts which became apparent through actions taken by the participants, both individual and organized (Table 5). Impacts were identified by a combination of a survey done by the organizers with participants, but also through groups not attending the course that approached the organizers, showing that the course influence was far beyond the course participants. The creation of a Coastal Commission by the municipalities in Montevideo, and the fact that secondary school teachers and professionals showed interested in attending the next edition of the course, are to be highlighted as the most important post-course positive impacts.

Taken as a whole, the Virtual Course on Integrated Coastal and Marine Management contributed to coastal sustainability, which is undermined by traditional sectorial management (Fig. 2; 1), by creating capacities, increasing awareness, and developing networks, agendas and priority issues for municipal and provincial coastal actors (Fig. 2; 2-3), thus improving the basis for better coastal governance. These direct contributions have indirect associated consequences for coastal sustainability since capacities and actions towards strategic planning are developed (Fig. 2; 4-5), slowly producing more benefits and less impact on coastal ecosystems and resources. The course showed other indirect benefits, not pursued originally, including opportunities for local coastal managers to better address issues of strategic planning in the future, links with the private sector operating on the coast (as seen previously; Table 5) and the potential for the participants to promote the principles they learned during the course, at the local level (Fig. 2; 7). These interrelated benefits and synergies, if replicated annually to reach more stakeholders of the coastal zone of Uruguay (as it is planned), will surely contribute, in the long term, to a more sustainable use of coastal ecosystems and resources (Fig. 2; 6).

Table 5. Post-course impacts derived from several actions and interactions which occurred from weeks to months after the course ended. Tabela 5. Impactos do curso após sua conclusão.

\begin{tabular}{l|l}
\hline \multicolumn{1}{c|}{ Province } & \multicolumn{1}{c}{ Post-course impact } \\
\hline Montevideo & The creation of a Coastal Commission by municipalities \\
\hline Maldonado & Development of an agenda addressing priority coastal topics by municipalities \\
\hline \multirow{2}{*}{ San José } & $\begin{array}{l}\text { Request to the Universidad de la República to carry out specific studies on coastal problems (e.g. erosion } \\
\text { in Kiyú gullies; breakwaters in Cufré stream mouth) }\end{array}$ \\
\hline \multirow{2}{*}{$\begin{array}{l}\text { Geographically non } \\
\text { specific }\end{array}$} & $\begin{array}{l}\text { Proposal for new virtual courses on specific topics focusing on erosion, environmental education, and } \\
\text { legal aspects of the coast }\end{array}$ \\
\cline { 2 - 2 } & Interest expressed by several teachers from Secondary School to attend the course \\
\cline { 2 - 2 } & Interest expressed by professionals of diverse disciplines to attend the course \\
\hline
\end{tabular}




\section{LOCAL COASTAL SYSTEM}

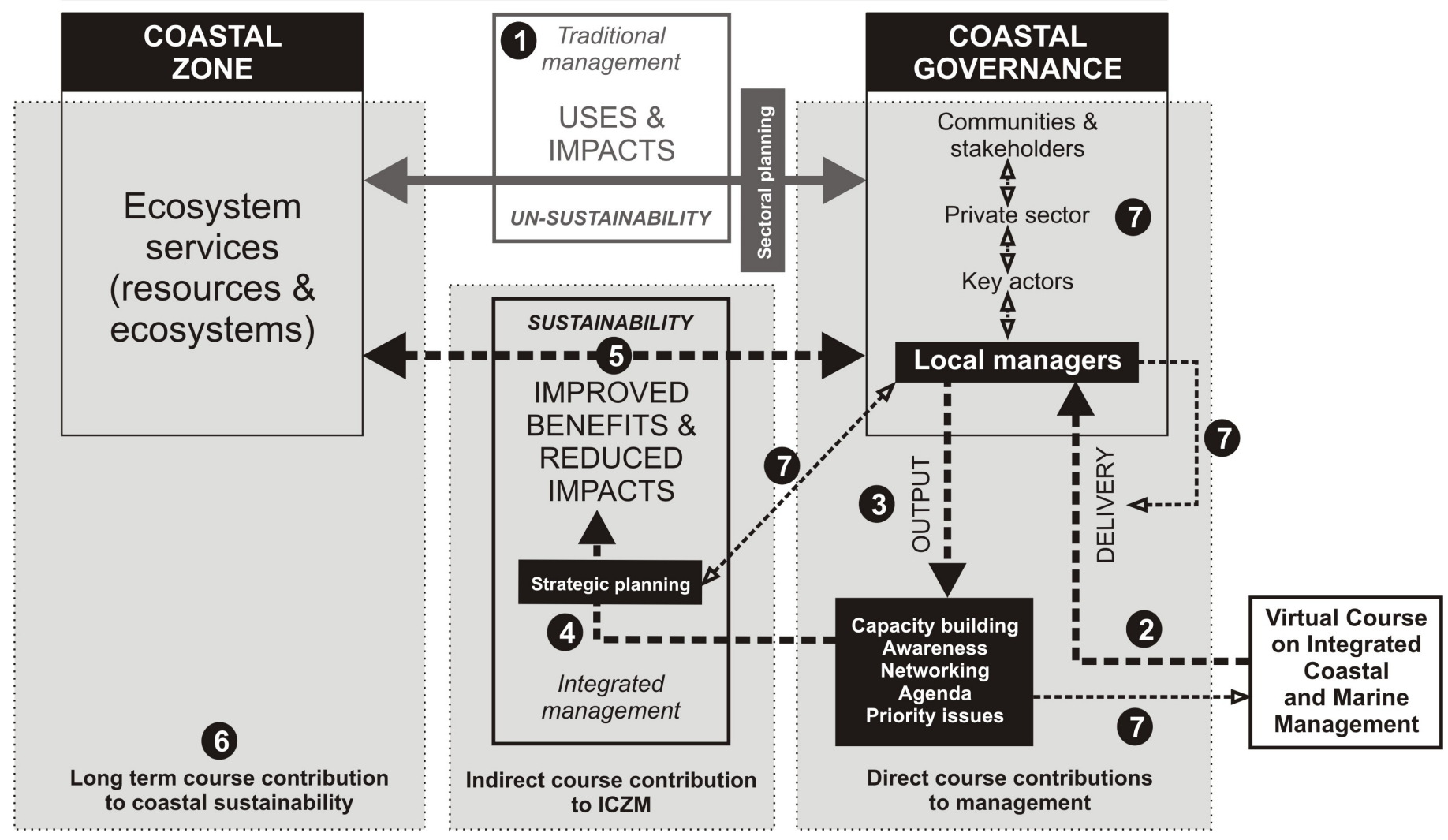

Figure 2. Contribution of the Virtual Course on Integrated Coastal and Marine Management to the advancement of ICZM in Uruguay (see explanations and details in the text).

Figura 2. Contribuição do Curso Virtual em Gestão Integrada da Zona Costeira no desenvolvimento da GIZC no Uruguai (ver explicação no texto).

\section{REFERENCES}

Barquera, H. (1986) - Una Revisión Sintética de Investigación Participativa. In: Picón C. (comp.), Investigación participativa: Algunos aspectos criticos y problemáticos, pp.36-49, CREFAL - Centro de Cooperación Regional para la Educación de Adultos en América Latina y el Caribe, Pátzcuaro Michoacán, México. Available at: http://www.crefal.edu.mx/crefal25/images/publicaciones/ cuadernos_crefal/cuadernos_crefal_18.pdf

Barragán Muñoz, JM. (coord.). (2012) - Manejo Costero Integrado en Iberoamérica: Diagnóstico y propuestas para una nueva politica pública. Red IBERMAR (CYTED), Cádiz, 152 pp. Available at: http:/grupos.uca.es/ HUM1 17/ibermar/Resultados\%20y\%20descargas/ publicacionibermariii/publicacionibermariii

Baztan, J.; Vanderlinden, J-P.; Chouinard, O.; Sanchez Arcilla, A.; Ernstein, R.; Noblet, M.; Plante, S.; Jorgensen, B.; Henocque, Y., Pacheco, A.; Konstantinou, Z.; McFadden, Paulet, Y-M.; Botero, C.; Gutiérrez Gálvez, C.; Ranasinghe, R.; Delgado Fernandez, I.; Sommer, M.; Conde, D. (2012) - Los desafios de las zonas costeras en el siglo XXI: propuestas para la Cumbre de la Tierra Rio+20. Available at: www.oannes.org.pe/ upload/201204171439101576153038.pdf

Beaudoin, Y.; Pendleton, L. (2012) - Why value the oceans. The Economics of Ecosystems and Biodiversity.
(TEEB) Available at: www.teebweb.org/wp-content/ uploads/2013/04/2013-TEEB-for-Oceans-DiscussionPaper.pdf

Cicin-Sain, B.; Knecht, R.W. (1998) - Integrated coastal and ocean management: Concepts and practices. Island Press:Washington D.C. ISBN 1-55963-603-3

Christie, P.; Lowry, K.; White, A.T.; Oracion, E.G.; Sievanen, L.; Pomeroy, R.S.; Eisma, R.L. V. (2005) - Key findings from a multidisciplinary examination of integrated coastal management process sustainability. Ocean \& Coastal Management, 48(3):468-483. Doi: 10.1016/j. ocecoaman.2005.04.006.

Conde D.; de Álava, D.; Gorfinkiel, D.; Menafra, R.; Roche, I.; (2012) - Sustainable coastal management at the public university in Uruguay: a Southern Cone perspective. In: W. Leal (Ed.) Sustainable Development at Universities: New Horizons, pp.873-885, Peter Lang Scientific Publishers, Frankfurt, Germany. ISBN: 9783631625606.

Crawford, B.R.; Stanley, J.; Friedman, A. (1993) - Building capacity for integrated coastal management in developing countries. Ocean \& Coastal Management, 21(1):311337. DOI: 10.1016/0964-5691(93)90033-U

da Silva, C.A.; Andrade Rainha, F. (2013) - Metodologia de Ensino de Educação Ambiental em Escola Situada na Área Costeira da Baía de Guanabara. Journal of Integrated Coastal Zone Management 13(2):181-192. DOI:10.5894/rgci399 
Dias, J. A.; Michaelovitch, M; Cearreta, A. (2012) - Coastal Management: the result of a doubtful relationship between Man and Nature. Journal of integrated Coastal Zone Management, 12(1):3-6. Available at: http://www. aprh.pt/rgci/pdf/rgci-331_Dias.pdf

Domínguez, A. (2011) - Desafíos actuales de la Educación Ambiental. In: Tarouco de Azevedo et al. (orgs.), Encontro e diálogos com a Educaçao Ambiental, pp.33-41, FURG, Río Grande, RG, Brasil.

Ehler, C.; Douvere, F. (2007) - Visions for a sea change. Report of the first international workshop on marine spatial planning. 83p., Intergovernmental Oceanographic Commission and Man and the Biosphere Programme, UNESCO, Paris, France. Available at: http://www.unesco-ioc-marinesp.be/ uploads/documentenbank/322a25f624fcb940dc70d0b3b 510de24.pdf

Fals-Borda, O. (1981) - The challenge of action research. Development Seeds of Change 1:55-61.

Ferreira, A.; Lopes, M.; Morais, J. (2006) - Environmental management and audit schemes implementation as an educational tool for sustainability. Journal of Cleaner Production, Volume 14(9-11):973-982. Doi: 10.1016/j. jclepro.2006.01.003

Gunderson, L. (1999) - Resilience, flexibility and adaptive management-antidotes for spurious certitude? Conservation Ecology, 3(1):art7. Available at: www.consecol.org/vol3/ iss $1 /$ art7/

GEO Uruguay (2008) - GEO Uruguay 2008. Informe del estado del Ambiente. 350p., Programa de Naciones Unidas para el Medio Ambiente (PNUMA) / Centro Latino Americano de Ecología Social (CLAES) / Dirección Nacional de Medio Ambiente (DINAMA), Montevideo, Uruguay. Available at: http://www.ambiental.net/noticias/ reportes/GeoUruguay2008.pdf

Hesselink, Frits; Čeřovsky, Jan (2008) - Learning to Change the Future $A$ bird's-eye view of the history of the IUCN Commission on Education and Communication. 22p., IUCN - International Union for Conservation of Nature, Gland, Switzerland. http://cmsdata.iucn.org/downloads/ cec_history_30sept08_draft.pdf

Holling, C.S. (ed.) (1978) - Adaptive Environmental Assessment and Management. 377p., John Wiley \& Sons, Chichester, U.K. ISBN: 0471996327. Available at http:// webarchive.iiasa.ac.at/Admin/PUB/Documents/XB-78103.pdf

Martínez Agut, M.P.; Aznar Minguet, P.; Ull Solís, A.; Piñero, A. (2007) - Promoción de la sostenibilidad en los currícula de la enseńanza superior desde el punto de vista del profesorado: un modelo de formación por competencias. Educatio Siglo XXI (ISSN: 1699-2105), 25:187-208, Murcia, España. Available at http://revistas. um.es/educatio/article/viewFile/721/751

May, P. J.; Williams, W. (1986) - Disaster Policy Implementation: Managing Programs Under Shared Governance. 198p., Plenum Press, New York, NY, U.S.A. ISBN: 9780306421792

Menafra, R.; Conde, D.; Roche, I.; Gorfinkiel, D.; Píriz, C.; Baliero, W.; Biasco, E.; Fossati, M.; Lorenzo, E.; Cortazzo, R.; Fournier, R. (2009) - Challenges and perspectives for integrated coastal management in Uruguay. Ocean Yearbook, 23:403-432
Norris-Raynbird, C. (2003) - Capacity-building: an inquiry into the local coastal program component of coastal zone management in Louisiana. Doctoral dissertation, Texas A\&M University. Available at: http://repository.tamu. edu/bitstream/handle/1969.1/5916/etd-tamu-2006ASOCI-NorrisR.pdf

Novo, M. (2009) - La educación ambiental: una genuina educación para el desarrollo sostenible. Revista de Educación (ISSN: 1988-592X), número extraordinario 2009: 195-217, Madrid, España. Available at http://www.revistaeducacion. mec.es/re2009/re2009_09.pdf

Olsen, S.; Ochoa, E. (2007) - El Porqué y el Cómo de una Línea de Base para Gobernanza en los Ecosistemas Costeros. 31p., Guayaquil, Ecuador. Available at http://www.procostas. org/cms/docs/porque_y_como_Ochoa-Olsen.pdf

Pomeroy, R.; Douvere, F. (2008) - The engagement of stakeholders in the marine spatial planning process. Marine Policy, 32(5):816-822. Doi:10.1016/j.marpol.2008.03.017

Sinha, Savita; Jangira, N.K.; Das, Supta (1985) Environmental Education Module for Pre-Service Training of Social Science Teachers and Supervisors for Secondary Schools. 123p., UNESCO - United Nations Educational, Scientific and Cultural Organization, UNEP International Environmental Education Programme, National Council of Educational Research and Training, New Delhi, India. Available at http://unesdoc.unesco. org/images/0006/000650/065036e.pdf

Sorensen, J.C.; West, N. (1992) - A guide to impact assessment in coastal environments. 100p., Coastal Resources Center, University of Rhode Island, Kingston, RI, U.S.A. Available at: http://pdf.usaid.gov/pdf_docs/PNABX551.pdf

Smith, S.; Pyrch, T.; Lizardi, A. O. (1993) - Participatory actionresearch for health. World Health Forum, 14:319-324

UNEP / UNESCO (2012) - YouthXchange Guidebook Series Biodiversity and Lifestyles. 5p., e-paper, UNEP United Nations Environment Programme / UNESCO - United Nations Educational, Scientific and Cultural Organization, Paris, France. Available at: http://unesdoc. unesco.org/images/0021/002179/217903E.pdf

Walters, C. (1986) - Adaptive management of renewable resources. 374p., McGraw Hill, New York, NY, U.S.A. ISBN: 9780070680289.

Young, O.; Oshrenko, G.; Ekstrom, J.; Crowder, L.; Ogden, J.; Wilson, J.; Day, J.; Douvere, F.; Ehler C.; McLeod, K.; Halpern, B.; Peach, R. (2007) - Solving the crisis in ocean governance. Place-based management of marine ecosystems. Environment: Science and Policy for Sustainable Development (ISSN: 0013-9157), 49:21-30, Philadelphia, PA, U.S.A. 